\title{
Statin on insulin and adiponectin levels: true or false prophecy?
}

This article was published in the following Dove Press journal: Diabetes, Metabolic Syndrome and Obesity:Targets and Therapy

\author{
Venu Gopal Jonnalagadda' \\ Afsar Shaik ${ }^{2}$ \\ 'Department of Pharmacology \& \\ Toxicology, National Institute of \\ Pharmaceutical Education and \\ Research, Bhangagarh, Guwahati, \\ Assam, India; ${ }^{2}$ Department of \\ Pharmacology, Narayana Pharmacy \\ College, Chinthareddy Palem, Nellore, \\ Andhra Pradesh, India
}

\section{Dear editor}

We read the article "Effect of different doses of statins on the development of type 2 diabetes mellitus in patients with myocardial infarction" by Gruzdeva et $\mathrm{al}^{1}$ with interest. The authors conducted a prospective cohort study on patients with diagnosed myocardial infarction who were on different doses of atorvastatin, ie, $20 \mathrm{mg} / \mathrm{d}$ or $40 \mathrm{mg} / \mathrm{d}$, for new onset of diabetes for a duration of 12 months.

In the results, the authors presented that (Table 2) the levels of insulin in group 1 (atorvastatin $20 \mathrm{mg} / \mathrm{d}$ ) were $12.95 \mathrm{mU} / \mathrm{mL}(8.50 ; 14.60)$ on day 1 and $9.96 \mathrm{mU} / \mathrm{mL}$ $(7.40 ; 12.70)$ at 1 year. In same vein, the levels of insulin in group 2 (atorvastatin $40 \mathrm{mg} / \mathrm{d})$ were $12.5 \mathrm{mU} / \mathrm{mL}(8.90 ; 15.92)$ on day 1 and $12.67 \mathrm{mU} / \mathrm{mL}(9.74 ; 15.70)$ at 1 year. Moreover, the levels of adipokines (Table 3), ie, adiponectin, in group 1 (atorvastatin $20 \mathrm{mg} / \mathrm{d}$ ) were $9.1 \mathrm{mg} / \mathrm{mL}(7.10 ; 12.40)$ on day 1 and $14.4 \mathrm{mg} / \mathrm{mL}(10.70$; 17.00 ) at 1 year. In the case of group 2 , the levels (atorvastatin $40 \mathrm{mg} / \mathrm{d}$ ) were $8.7 \mathrm{mg}$ / $\mathrm{mL}(5.50 ; 12.80)$ on day 1 and $10.6 \mathrm{mg} / \mathrm{mL}(7.40 ; 12.80)$ at 1 year. ${ }^{1}$

After careful consideration, it can be understood that increased dose of statin did not affect insulin and adiponectin levels in a dose-dependent manner. In contrast to this, there were eight cases (20.5\%) in the atorvastatin $40 \mathrm{mg} / \mathrm{d}$ group and one case $(2.6 \%)$ in the atorvastatin $20 \mathrm{mg} / \mathrm{d}$ group diagnosed with new onset of diabetes out of 39 patients in each group. ${ }^{1}$

In general, and accumulating data reiterates that, statins cause dose-dependent decrease in the levels of adiponectin and insulin and increase in the levels of glucose, ie, hyperglycemia. On the contrary, the authors presented that the levels of glucose increased along with insulin and adiponectin levels rather than decreased..$^{2-4}$

We would be much obliged if you would kindly clarify these issues, and we also believe that managing cardiovascular events is important with statins after assessing the risk versus benefit ratio.

\section{Disclosure}

The authors report no conflicts of interest in this communication.

\section{References}

1. Gruzdeva O, Uchasova E, Dyleva Y, et al. Effect of different doses of statins on the development of type 2 diabetes mellitus in patients with myocardial infarction. Diabetes Metab Syndr Obes. 2017;10:481-489.

2. Sattar N, Taskinen MR. Statins are diabetogenic - myth or reality? Atheroscler Suppl. 2012;13:1-10.

3. Jonnalagadda VG, Choudhary K, Matety VK. Statins and new onset of diabetes: which one outweighs risk or benefit? Postgrad Med. 2018:130(1):146.

4. Maki KC, Diwadkar-Navsariwala V, Kramer MW. Statin use and risk for type 2 diabetes: what clinicians should know. Postgrad Med. 2017;22:1-7.

Tel +9892588207

Email gopalvenu63@gmail.com 


\section{Authors' reply}

\section{Evgenya Uchasova Olga Gruzdeva}

Federal State Budgetary Institution, Research Institute for Complex Issues of Cardiovascular Diseases, Kemerovo, Russian Federation

\section{Correspondence: Evgenya Uchasova}

Federal State Budgetary Institution, Research Institute for Complex Issues of Cardiovascular Disease, Laboratory of Research Homeostasis, 6 Sosnovy Boulevard, Kemerovo 650002, Russian Federation

Tel +7 3842640553

Fax +73842643410

Email evg.uchasova@yandex.ru

\section{Dear editor}

We would like to thank Venu Gopal Jonnalagadda and Afsar Shaik for the letter in response to our article. ${ }^{1}$ Yes, indeed in our study, statins at a dose of 20 and $40 \mathrm{mg} / \mathrm{mL}$, at $20 \mathrm{mg} / \mathrm{d}$ atorvastatin, were observed to improve the sensitivity to insulin and eliminate adipokine imbalance and ghrelin deficiency. At a dose of $40 \mathrm{mg} / \mathrm{d}$, atorvastatin showed increased negative effects, such as a reduction in insulin secretion, hyperglycemia, impaired glucose tolerance, high levels of leptin, ghrelin deficiency, and manifestation of type 2 diabetes mellitus. Statins at a dose of $80 \mathrm{mg} / \mathrm{mL}$ were not included in this work; however, at this dose in this study, we observed a decrease in levels of adiponectin and insulin. ${ }^{1}$

\section{Disclosure}

The authors report no conflicts of interest in this communication.

\section{Reference}

1. Gruzdeva O, Uchasova E, Dyleva Y, et al. Effect of different doses of statins on the development of type 2 diabetes mellitus in patients with myocardial infarction. Diabetes Metab Syndr Obes. 2017;10:481-489.
Diabetes, Metabolic Syndrome and Obesity: Targets and Therapy is an international, peer-reviewed open-access journal committed to the rapid publication of the latest laboratory and clinical findings in the fields of diabetes, metabolic syndrome and obesity research. Original research, review, case reports, hypothesis formation, expert opinion and commentaries are all considered for publication. The manuscript management system is completely online and includes a very quick and fair peer-review system, which is all easy to use. Visit http://www.dovepress.com/testimonials.php to read real quotes from published authors. 